\title{
Sistem Informasi Fasilitas Umum Di Kota Palembang Berbasis Android
}

\author{
Irma Salamah', Sopian Soim², Fathria Nurul Fadillah ${ }^{3}$ \\ 1,2,3Program Studi Teknik Telekomunikasi, Politeknik Negeri Sriwijaya, Jl. Srijaya Negara Bukit \\ Besar, Palembang, 30139 \\ irma.salamah@yahoo.com, sopian_soim2005@yahoo.com,fathrianf@gmail.com
}

\begin{abstract}
As the capital city of South Sumatera Province, Palembang has several public facilities to support the needs of the community.Information about public facilities such as hospitals, puskesmas, police stations and malls will be needed by the community, especially newcomers in Palembang.This information system is implemented in Android based applications and developed using Android Studio as well as MySQL as a database.The information contained in the application is the name of the public facility, address, telephone number and instructions to the location of public facilities.
\end{abstract}

Keywords: Information System, Public Facilities, Palembang City, Android

Abstrak

Sebagai ibukota Provinsi Sumatera Selatan, Kota Palembang memiliki beberapa fasilitas umum untuk menunjang kebutuhan masyarakatnya. Informasi mengenai fasilitas umum seperti rumah sakit, puskesmas, kantor polisi dan mall akan sangat dibutuhkan oleh masyarakat khususnya pendatang baru di Kota Palembang. Sistem informasi ini diterapkan dalam aplikasi berbasis android dan dikembangkan dengan menggunakan Android Studio serta MySQL sebagai database. Informasi yang dimuat dalam aplikasi berupa nama fasilitas umum, alamat, nomor telepon dan petunjuk menuju lokasi fasilitas umum.

Kata kunci: Sistem Informasi, Fasilitas Umum, Kota Palembang, Android

\section{PENDAHULUAN}

Dewasa ini, teknologi memegang peranan penting dalam kehidupan seharihari. Dengan perkembangan yang ada, kian menjadikannya sesuatu yang berguna disegala aspek kehidupan manusia. Smartphone merupakan salah satu teknologi yang dapat memberikan kemudahan bagi penggunanya dalam melakukan aktivitas sehari-hari [1]. Dengan smartphone, pengguna dapat mengakses segala informasi yang dibutuhkan dengan mudah dan cepat. Kota Palembang merupakan ibukota Provinsi Sumatera Selatan yang memiliki luas wilayah 400,61 km² [2]. Dengan luasnya wilayah yang dimiliki, pemerintah Kota Palembang diwajibkan untuk menyediakan fasilitas umum seperti rumah sakit, puskesmas, kantor polisi dan mall sebagai media pelayanan masyarakat. Seiring dengan perkembangan zaman, akses mengenai informasi fasilitas umum tersebut dapat dengan mudah didapatkan melalui smartphone. Terlebih bagi pendatang baru di Kota Palembang, informasi tersebut akan sangat membantu apabila terjadi suatu hal yang mendesak. 
Pada penelitian sebelumnya, telah dibangun sebuah website mengenai sistem geografis fasilitas umum Kota Palembang [3]. Akan tetapi fasilitas yang dibangun tidak dijelaskan secara detail pada penelitian tersebut dan juga performansi website masih belum maksimal. Oleh karena itu, penulis mengembangkan sebuah aplikasi berbasis android untuk membantu masyarakat dan pendatang baru untuk dapat mengakses informasi mengenai fasilitas umum seperti rumah sakit, puskesmas, kantor polisi dan mall. Informasi tersebut berupa nama fasilitas umum, alamat, nomor telepon dan petunjuk menuju lokasi fasilitas umum.

\section{METODOLOGI PENELITIAN}

Metode penelitian yang digunakan dalam pengembangan aplikasi ini adalah metode Waterfall dengan tahapan sebagai berikut:

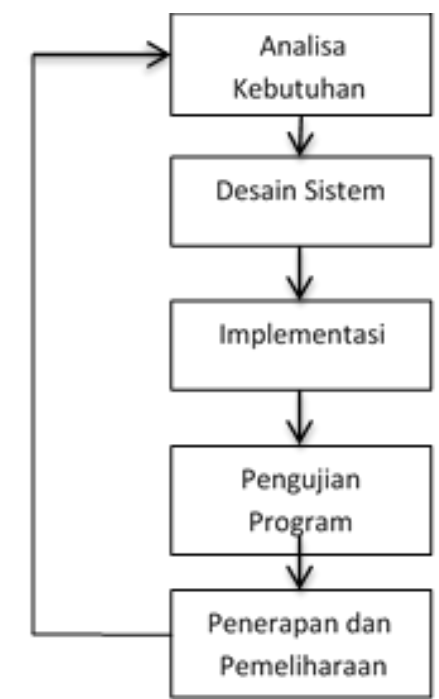

Gambar 1. Metode Penelitian Waterfall

a) Analisa Kebutuhan

Pada tahap ini, penulis menganalisa kebutuhan sistem seperti fitur-fitur yang akan disediakan pada aplikasi. Mulai dari pilihan fasilitas umum seperti rumah sakit, puskesmas, kantor polisi dan mall, daftar nama-nama fasilitas umum dan informasi mengenai fasilitas umum tersebut yang berupa nama, alamat, nomor telepon dan petunjuk.

b) Desain Sistem

Penulis menentukan desain untuk membangun aplikasi. Yakni penulis menentukan desain layout dan warna pada setiap halaman aplikasi. Warna yang digunakan adalah biru tosca dan abu-abu.

c) Implementasi

Pada tahap ini dilakukan penerapan desain sistem ke dalam bahasa pemrograman yakni Java dan XML. 
d) Pengujian Program

Tahap ini bertujuan untuk menguji apakah hasil implementasi desain berjalan dengan baik pada sistem operasi android.

e) Penerapan dan Pemeliharaan

Merupakan tahapan terakhir dimana aplikasi yang telah dibangun diperiksa secara menyeluruh apakah terjadi error atau tidak.

\section{HASIL DAN PEMBAHASAN}

\subsection{Hasil}

Penelitian ini menghasilkan keluaran berupa sebuah aplikasi yang berjalan pada sistem operasi minimum Android 5.0 (Lollipop) dengan menampilkan informasi mengenai fasilitas umum di Kota Palembang. Fasilitas umum yang termasuk dalam menu utama pada aplikasi ini adalah rumah sakit, puskesmas, kantor polisi dan mall. Adapun informasi yang terdapat pada masing-masing fasilitas umum adalah nama, alamat, nomor telepon serta petunjuk menuju fasilitas umum tersebut. Aplikasi yang dikembangkan diberi nama P3Finder (Palembang Public Place Finder). Berikut adalah tampilan dari setiap halaman yang ada pada aplikasi ini:

a) Tampilan GPS Permission

Pada tampilan awal aplikasi, akan terdapat splash screen dengan toast message berupa permintaan akses untuk mengaktifkan GPS. Tujuan diaktifkannya GPS adalah untuk mengetahui posisi pengguna. Tampilan tersebut dapat dilihat pada gambar dibawah ini.

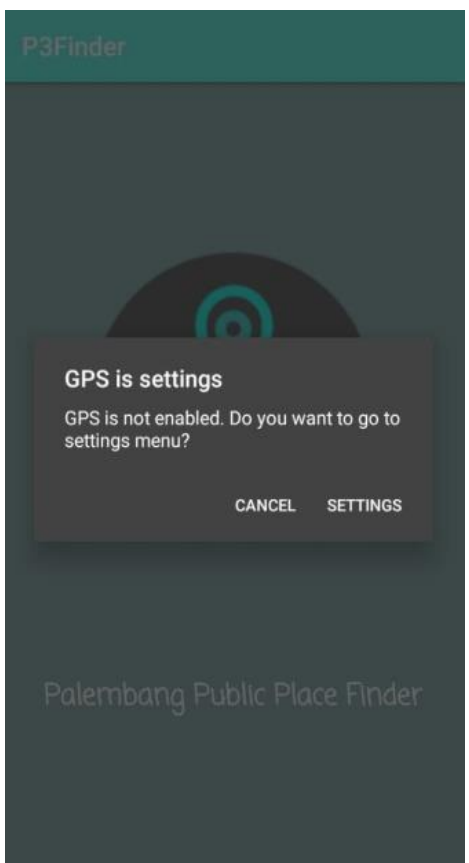

Gambar 2. Halaman GPS Permission 
b) Tampilan Splash Screen

Halaman ini memuat logo dari aplikasi P3Finder dengan tambahan toast message yang berisi latitude dan longitude pengguna. Dengan catatan, GPS pengguna telah diaktifkan dengan akurasi tingkat tinggi. Tampilan splash screen dapat dilihan pada gambar berikut:

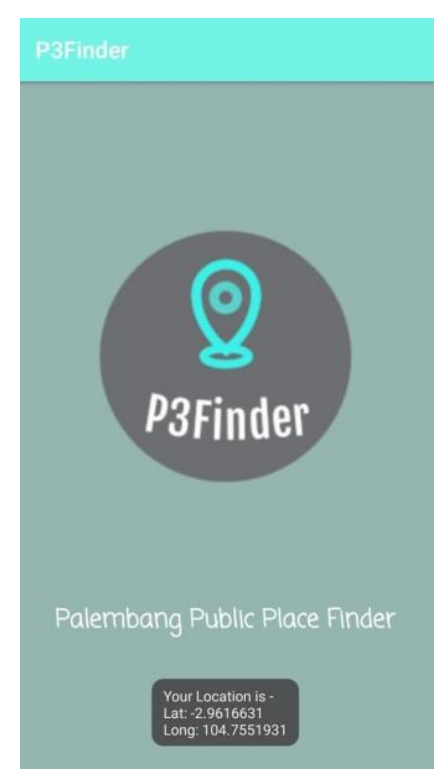

Gambar 3. Halaman Splash Screen

c) Tampilan Menu Utama

Pada halaman utama terdapat 4 pilihan fasilitas umum antara lain rumah sakit, puskesmas, kantor polisi dan mall. Tampilan tersebut dapat dilihat pada gambar di bawah ini:

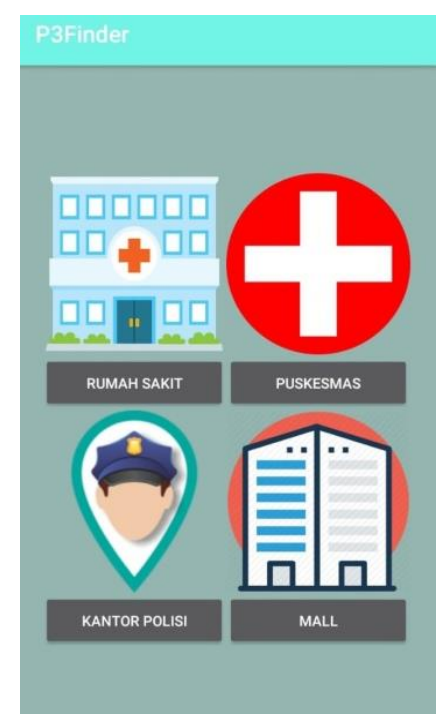

Gambar 4. Halaman Menu Utama 
d) Tampilan Daftar Rumah Sakit

Pada gambar di bawah ini akan diperlihatkan daftar rumah sakit yang tersedia di Kota Palembang dengan jarak terdekat dari pengguna. Tampilan ini dibuat dengan menggunakan ListView pada Android Studio.

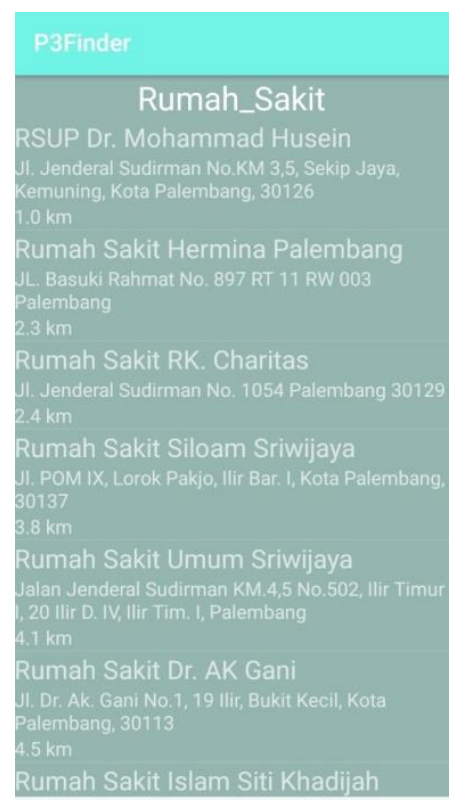

Gambar 5. Halaman Daftar Rumah Sakit Terdekat

e) Tampilan Informasi Rumah Sakit

Pada halaman ini akan memuat informasi mengenai rumah sakit yang dipilih oleh pengguna, dalam hal ini RSUP Dr. Mohammad Husein. Tampilan tersebut dapat dilihan pada gambar berikut:

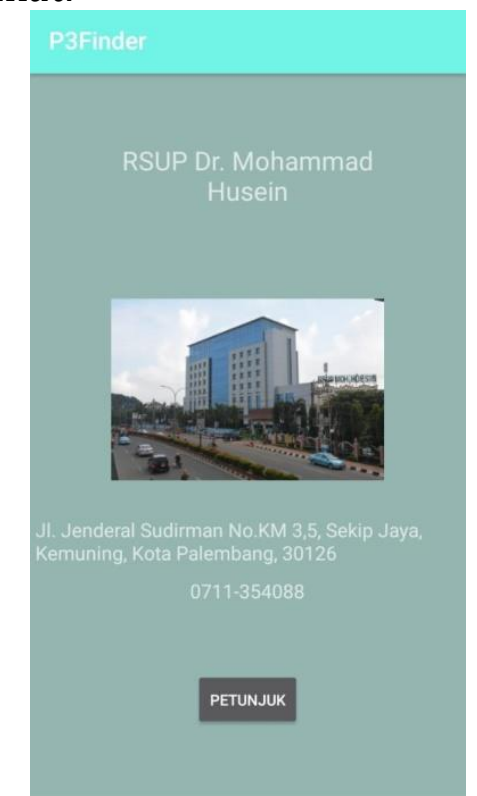

Gambar 6. Halaman Informasi Fasilitas Umum 
f) Tampilan Petunjuk

Pada halaman sebelumnya, terdapat informasi fasilitas umum serta tombol petunjuk yang ada di bawahnya. Tombol petunjuk tersebut berguna sebagai navigasi bagi pengguna saat menuju ke fasilitas umum yang dituju dan ditampilkan langsung oleh Google Maps. Berikut adalah tampilan dari hasil tombol petunjuk:

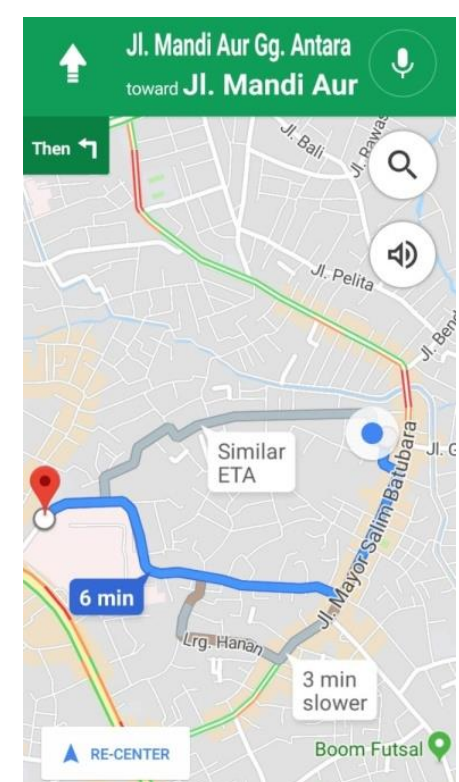

Gambar 7. Halaman Petunjuk

\subsection{Pembahasan}

Gambar 5-7 merupakan contoh salah satu fasilitas umum beserta informasinya yang terdapat pada aplikasi P3Finder. Untuk fasilitas umum lainnya seperti puskesmas, kantor polisi dan mall memiliki format informasi yang sama seperti gambar-gambar di atas. Yang membedakan hanya isi dari informasi tersebut. Berikut adalah hasil pengujian fungsional dari setiap halaman yang ada pada aplikasi:

Tabel 1. Hasil Pengujian

\begin{tabular}{|c|l|c|c|}
\hline \multirow{2}{*}{ No. } & \multirow{2}{*}{ Halaman yang Diuji } & \multicolumn{2}{|c|}{ Hasil Pengujian } \\
\cline { 3 - 4 } & & Berhasil & Gagal \\
\hline 1. & GPS Permission & $\mathrm{v}$ & - \\
\hline 2. & Splash Screen & $\mathrm{v}$ & - \\
\hline 3. & Menu Utama & $\mathrm{v}$ & - \\
\hline 4. & Daftar Fasilitas Umum Terdekat & $\mathrm{v}$ & - \\
\hline 5. & Informasi Fasilitas Umum & $\mathrm{v}$ & - \\
\hline 6. & Petunjuk & $\mathrm{v}$ & - \\
\hline
\end{tabular}




\section{SIMPULAN}

Pada penelitian ini telah dihasilkan sebuah aplikasi mengenai sistem informasi fasilitas umum di Kota Palembang. Aplikasi ini berjalan pada sistem operasi Android yang merupakan pengembangan dari penelitian sebelumnya dimana sistem informasi dikembangkan dalam bentuk website. Diharapkan aplikasi yang penulis kembangkan dapat bermanfaat terutama bagi pendatang baru di Kota Palembang agar mendapatkan informasi secara cepat dan akurat apabila terjadi suatu hal yang mendesak.

\section{DAFTAR PUSTAKA}

[1] H. N. Lengkong, A. A. E. Sinsuw, and A. S. . Lumenta, "Perancangan Penunjuk Rute Pada Kendaraan Pribadi Menggunakan Aplikasi Mobile GIS Berbasis Android yang Terintegrasi pada Google Maps," E-journal Tek. Elektro dan Komput., pp. 18-25, 2015.

[2] Dinas Komunikasi dan Informatika Kota Palembang, "Portal Resmi Pemerintah Kota Palembang," 2018. [Online]. Available: http://www.palembang.go.id/beranda.

[3] I. P. Rudianto Rusli, Dentari Suhardi, "Sistem Informasi Geografis Fasilitas Umum Kota Palembang," no. 14, pp. 1-8, 2015. 